\title{
SOCIAL INTERACTION ASSESSMENT BETWEEN INSIDE AND OUTSIDE GATED HOUSING PROJECTS IN DISORDER RESIDENTIAL AREA
}

\author{
Background study of gated housing development in sprawl area \\ ゲーテッド・ハウジング・プロジェクトと既存の集落・住宅地が混在するエリアにおける \\ 居住者による近隣関係性の相互評価 \\ ースプロールエリアにおけるゲーテッド・ハウジング・プロジェクトの背景研究一
}

\author{
Siwaporn KLINMALAI* and Kiyoko KANKI** \\ シワポーンクリンマライ, 神吉 紀世子
}

\begin{abstract}
Gated housing project (GHP) in vicinity area of Bangkok is continuously expanding without well-urban planning. This situation leads to environmental and social problems on living conditions of residents in area. These problems can possibly disturb overall urban development plan in the future. This research aims to assess social relationship of inhabitants who live inside and outside GHP in order to illustrate its impact. Through field survey and social questionnaires in five types of existing community including GHP and Non-GHP within in study area conducted results of research. This study revealed obviously different social relationship between inside and outside residents that affirmed conflict and influence of GHP. Therefore, it is necessary for GHP to be addressed their physical design and concerned cautious regulation to reduce impacts on surrounding communities.
\end{abstract}

Keywords: Social Interaction Assessment, Gated Housing Project, Disorganized residential area 近隣居住者の評価，ゲーテッド・ハウジング・プロジェクト，コミュニティ混在地域

\section{Introduction}

\subsection{Research Background and Objective}

The vicinity area in Bangkok Metropolitan Region ${ }^{* 1)}$ (BMR) excessively has obtained infrastructure network, and population movement has increased especially in Nonthaburi province ${ }^{1)}$ according to the $6^{\text {th }}$ and $7^{\text {th }}$ National Economic and Social Development Plan ${ }^{2}$. This situation motivated broadly disorganization of residential land use, which appeared as a kind of modern housing projects (Fig. 3-B) on former paddy fields, which known as 'gated community' in U.S. ${ }^{3}$. But in this research, we call them Gated Housing Project (GHPs) (Fig.1). Although, the infrastructure was distributed thoroughly and orderly to a single community, the social and environmental problems between inside and outside GHP are existed. Because the increase of GHP changed the former villagers' occupation and lifestyle, and then led to bigger gap of social segregation which is related to problem of public participation for local government. Hence, the impact of GHP is important issue in developing vicinity area of BMR. This assumption bases on author's previous paper ${ }^{4}$ that revealed social problems caused by residential landform such as disconnection of former community network and spatial segregation in BMR. Pathumthani province, which is one of highly dense GHP areas, was examined about the social relationship inside and outside relationship ${ }^{5}$, which found social relationship of former village is much stronger than GHP, although they were enclosed by GHP's fences. This finding reflected GHP development had low impact on relationship of former villages in systematically equipped land use distribution in Pathumthani. Then, it is the next question whether the pattern of residential land distribution and attribute of residents is important factors to clarify the actual impact of GHP development on social assessment in specific area. Nonthaburi area has the highest migration in past decade and totally different land distribution from Pathumthani area; namely, the composition of lands has been more complicate and disorder according to natural cannel network (Fig.3). This situation led existing communities were isolated by GHP's physical elements and locations. Therefore, this paper focused on social interaction assessment of residents who live inside and outside GHP development in the disorganized land distribution. The aim of study is to illustrate the impact of GHP on social relationship. The prospected outcome is to offer and suggest the way to enhance social integration of GHP in Nonthaburi area.

\footnotetext{
* Doctoral Student, Dept. of Arch. and Arch. Eng., Grad. School of Eng., Kyoto Univ., M. Arch.

** Prof., Dept. of Arch. and Arch. Eng., Grad. School of Eng., Kyoto Univ., Dr. Eng.

京都大学工学研究科建築学専攻 博士課程・修士(建築)

京都大学工学研究科建築学専攻 教授・博士 (工学)
} 


\subsection{Definition and Terms}

(1) Community: When an identified community is a little village, its boundaries appear at first to be very simple. That pattern of human interaction may be seen as consisting only of relations between the residents living inside that location, inside that village. However, its residents interact also with people outside the village, the boundary of community is not so precise. Especially in urban community, its boundary became wider and more heterogeneity than rural community ${ }^{6}$. In study area, it may be seen as mixed type of community because the area has been developed from agricultural land into urbanized land. Hence, "community" in this paper means a group of people living together in residential area that might have or not have geographic boundary in planned or unplanned way. We found five types of community in Nonthaburi area, namely, 3 types with geographic boundary, which developed by developers, is 1) gated housing project with detached houses (GHP-D), 2) gated housing project with townhouse (GHP-T), and 3) housing project without gate (HP) community as well as 2 types without geographic boundary and originated in unplanned way, which are 4) former villages (FV), and 5) individual houses (IH).

(2) Social interaction assessment (SIA): Because disorder diffusion of GHP in BMR is rapid phenomena without urban planning, this phenomena influences on social interaction not only among residents who live inside GHP but outside ${ }^{5}$. According to previous work, Klinmalai and Kanki ${ }^{1)}$ found the impact of GHP on neighborhood relationship in Pathumthani area. That means GHP development related with social interaction. The SIA in this study includes three ways of investigations, which are showed questionnaire of neighborhood relationship, physical observation, and interview with relevant stakeholder.

(3) Neighborhood relationship: The definition of neighborhood relationship in this study is an interaction from individual person to neighbor and surrounding community. Therefore, neighborhood relationship in this study focuses on social interaction between residents inside community as "inside relationship assessment", and between inside resident and outside community or village as "outside relationship assessment". The inside relationship assessment's questions strived to examine sense of community inside community, while the outside relationship assessment's questions tried to evaluate behavior of residents outside community.

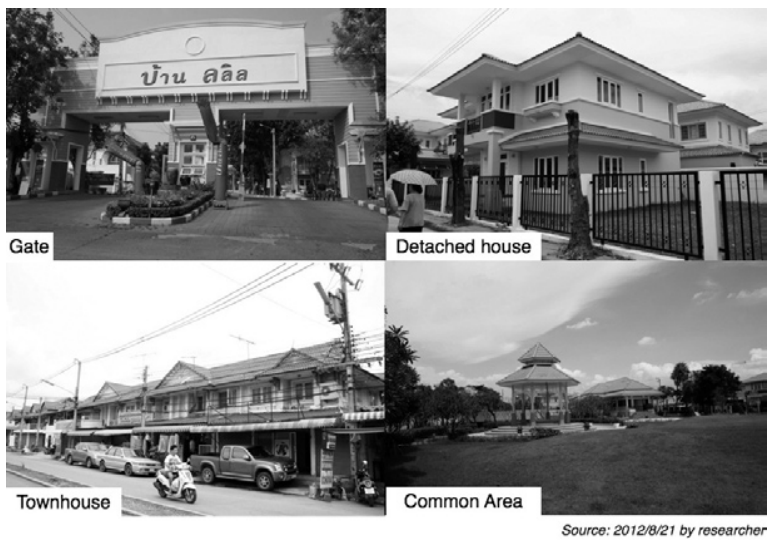

Fig.1 Gated Housing Project in BMR

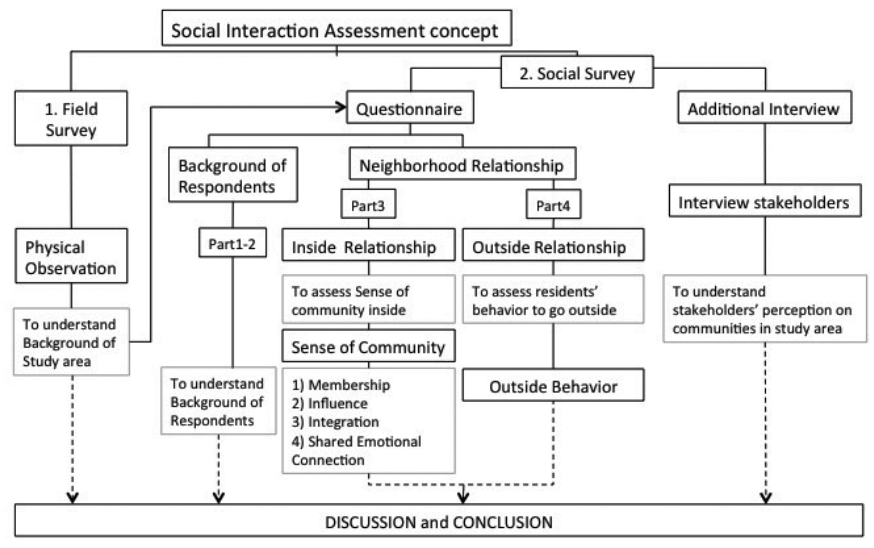

Fig.2 Research Methodology

(4) Gated Housing Project (GHP) Development: In BMR, the first housing project was constructed by public sector because they noticed inadequate situation of housing due to rapid population growth since 1967. Currently, private developers become the main players in housing estate market since $1977^{1}$. Majority of residential development is called Gated Housing Project (GHP), which is the same meaning with gated community (GCs) in America ${ }^{7}$. The physical design of GHP in BMR has slightly different from in US, although they expect to create a dreamed community as similar as US. The typical compositions of GHP in BMR are 1) Houses, 2) A gate with security guards, 3) Concrete fences enclosing project site, 4) Common facilities such as park, playground, club house, and 5) Basic infrastructure such as water supply, common road, and wastewater treatment (Fig.1). Only the gate with security guard and the concrete fence of project site are not determined by housing regulation in government gazette ${ }^{8}$. The aim of this governmental regulation is to set the standard of living for residents inside the GHP. Meanwhile the effect of GHP to the surrounding communities, especially social impact, is not considered in the housing regulation. The demand of GHP does not depend on the crime rate of the area, although GHP provides serious security system. In fact, GHP in BMR is considered as a perfect community for modern life because of its well-equipped environmental design ${ }^{7}$. Therefore, GHP has continuously been distributed in safe and unsafe residential area ${ }^{\left.{ }^{2}\right)}$, depending upon high migration rate and residential demand. It is important to carefully control GHP's increase because they probably affect inhabitants' life and environment.

\subsection{Research Methodology}

The social interaction assessment of this paper is conducted with two kinds of method (Fig.2); firstly, we studied background of study area to understand physical environment and existing situation in Nonthaburi area via field survey. Then we found five types of existing communities in study area that should be investigated. In order to understand the study area and the GHP situation in it, physical observation results were described (Chapter 3). Secondly, the structured questionnaires (Chapter 4) were randomly distributed to residents in five types of community. The questions were asked by face-to-face in order to clarify neighborhood relationship inside and outside communities. The result of questionnaire will be examined in Chapter 5. Then, the interview to relevant stakeholders such as developers and local government officers were summarized in chapter 6 as supportive results In summary, all results were discussed about different social interaction in all types of communities in Nonthaburi area, and proposed some suggestions for new GHP in the future in Chapter 7. 
Table 1 Population growth in BMR

\begin{tabular}{c|c|c|c|c|c|c}
\hline $\begin{array}{c}\text { Province in } \\
\text { BMR }\end{array}$ & $\begin{array}{c}\text { Area** } \\
\left(\mathrm{km}^{2}\right)\end{array}$ & 2004 & 2012 & \begin{tabular}{c} 
Population***ns \\
\cline { 3 - 7 }$\left(\mathrm{pp} / \mathrm{km}^{2}\right)$
\end{tabular} & $\begin{array}{c}\text { Population } \\
\text { growth }\end{array}$ & $\begin{array}{c}\text { Ratio*(1998) } \\
\text { Agricultural/total area }\end{array}$ \\
\hline Bangkok & $1,568.737$ & $5,6341,132$ & $5,673,560$ & $3,616.64$ & $+0.7 \%$ & 0.14 \\
\hline Nakhonpathom & $2,168.327$ & 789,016 & 874,616 & 403.36 & $+9.6 \%$ & 0.51 \\
\hline Nonthaburi & 622.303 & 942,292 & $1,141,673$ & $1,834.59$ & $+21.2 \%$ & 0.22 \\
\hline Pathumthani & $1,525.856$ & 769,998 & $1,033,837$ & 677.55 & $+34.3 \%$ & 0.46 \\
\hline Samuthprakarn & $1,004.092$ & $1,049,416$ & $1,223,302$ & $1,218.32$ & $+16.7 \%$ & 0.09 \\
\hline Samuthsakhon & 872.374 & 442,687 & 508,812 & 583.27 & $+14.9 \%$ & 0.26 \\
\hline TOTAL & $7,761.662$ & $9,636,541$ & $10,455,800$ & $1,347.11$ & $+8.5 \%$ & \\
\hline
\end{tabular}

Among five vicinity areas in BMR, Nonthaburi province is an area where urbanization is rapidly proceeding. Its population density is in the highest rank of all vicinities $\left(1,834.59 \mathrm{pp} / \mathrm{km}^{2}\right)$, while ratio of agricultural land use was not as small as 0.22 in 1998 (as shown in Table 1). The population growth of Nonthaburi province is the second rank of BMR $(+21.2 \%)$. One of the reasons of this increase might be the relocation of 29 governmental organizations to

Nonthaburi government center between 2007 and 2013. This situation might effect on residents' profile in district. The study area for field survey was Bangyai district with the highest migration rate in Nonthaburi province, which was $+9.10 \%$ in $2011^{1)}$. The area of Bangyai is $98.398 \mathrm{~km}^{2}$, and its number of household in 2012 was 58,045 families ${ }^{5}$. The agricultural land was approximately $48 \%$ of total area but agrarian households were $6.8 \%$ of whole families in Bangyai district $^{5}$. Formerly, this area was cultivated land and characterized by a dense canal network (Fig.3-D). Canal excavation was necessary for irrigated rice cultivation and water transport, which was the only transportation mode, because the canals were part of continental Chao Phraya delta (Fig.3-D). Many farmers who became original local people in this area migrated from Ayutthaya province around 14th-18th Century to cultivate paddy fields and orchards alongside the canals ${ }^{1}$. The alongside area of canal was utilized for planting and setting down their houses. Since modern infrastructure was spread from Bangkok city such as bridge and highway, the population and housing rate have been increased. Many fields have been urbanized into residential land use, new housing project developments (GHP), and located on the main road. However, these agrarian developments continued to influence land-use pattern after urbanization, resulting in a complex mosaic of rice fields, orchards, and residential land uses (Fig.3-A). This situation reflects comprising of a mosaic of urban and rural land uses through creating organic form plots of GHP. This situation is a representative of urbanization in suburban residential area of BMR. This could be assumed that Bangyai, Nonthaburi is the area where has been maximized urbanization on large agricultural land. Thus new residential development is highly possibility to impact existing agricultural area and local communities.

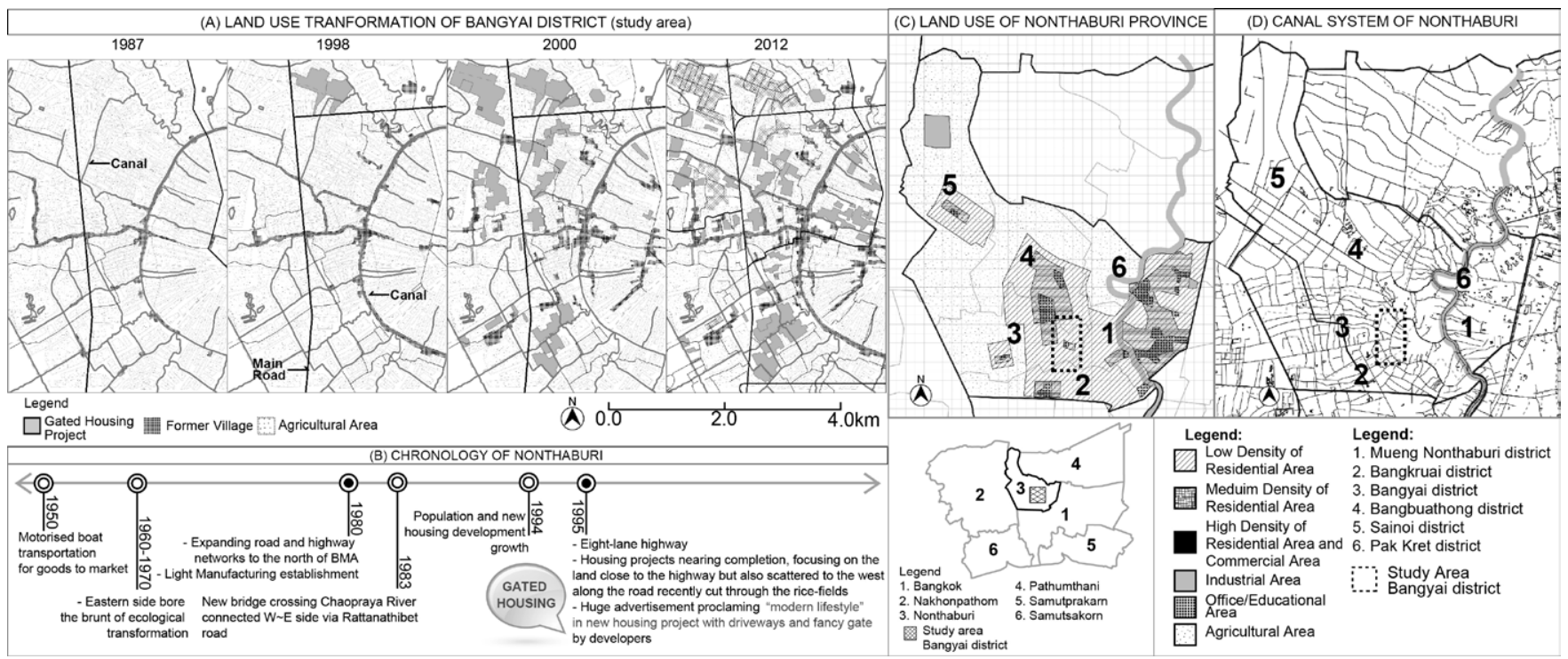

Fig.3 Background of Nonthaburi province and study area

\section{Field Survey: Characteristic of Gated Housing Development and Disorder Land distribution}

In study area, there are many temples and markets, which are public spaces in this district. The temples are in original locations, which are along the canals. The markets are places for agricultural products and fresh food for daily life. Moreover, we found five different types of community including; former village (FV), gated housing project with detached house (GHP-D), gated housing project with townhouse (GHP-T), housing project without gate (HP), and individual house (IH). The basic elements of GHP-D and GHP-T are same; having only one gate, enclosing project site by concrete fence, and providing common space for the residents inside. HPs used to be GHP, but the gate of HP was eliminated and security control was removed by residents' agreement because they could not support the cost. After HP became without the gate, the common corridor in the project site was given to local government. Some blocks of townhouse in HP are commercial function. The elimination of the gate enabled this business activity inside. The IH has unclear boundary as community. It located as a fragmental cluster along the road. From the current situation of study area, some primary problems can be discovered. Firstly, the disorder location among agricultural fields. This land use pattern resulted into the complex mosaic plots as mentioned in chapter 2. Secondly, we can notice that most of FVs are located beside the canals, while the other 4 types are nearby the road network. The road network system 
does not conform to canal system, especially, the highway that cut off the connection between streets in eastern and western side of study area. Thirdly, the location of FV and IH (Fig. 4) seems to be unintentionally enclosed by walls of GHP-D, GHP-T, or HP. Consequently, it is rather difficult for FV's residents to access road network

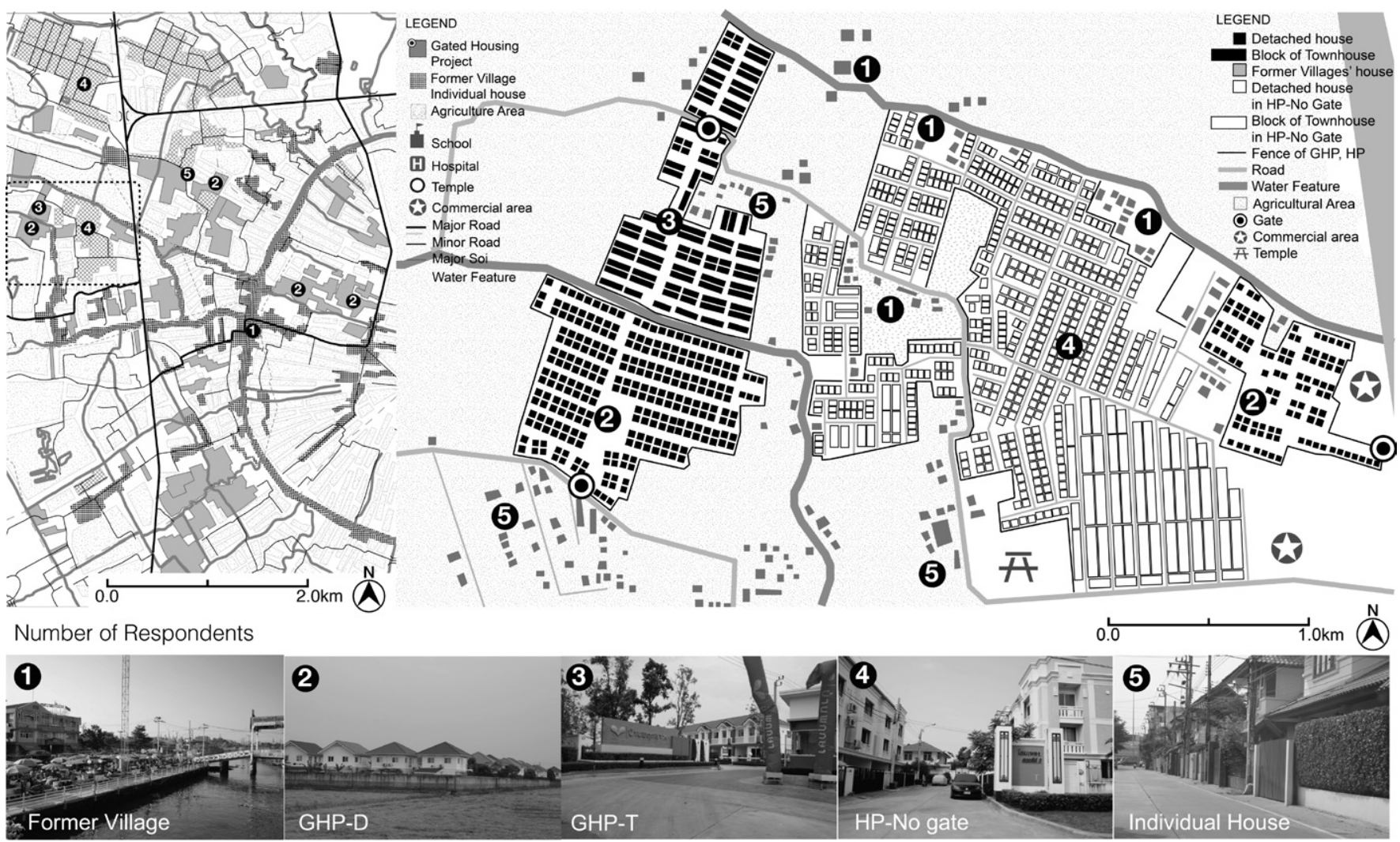

Fig.4 Five types of community in study area

\section{Social Interaction Assessment Analysis in Gated Housing Project Study}

As typical character of GHP is mentioned above, the impact of GHP on social problems are paid attention from many scholars in various aspects. For an instant, Blakely (1997) ${ }^{3)}$ found gated communities reflected to various degrees of four social values (sense of community, exclusion, privatization, and stability) in as positive social value for inside residents. His results supported that sense of community could be enhanced by physical neighborhood design. Buckner's (1988) ${ }^{9}$ finding also agreed that a well-defined boundary contributes to the connection to a particular place and the sense of community therein. The ultimate boundary of gated communities is often promoted as increasing sense of community. Meanwhile, Le Goix (2003) ${ }^{10)}$ mentioned about the discrepancy between a gated community and its surroundings are defined as a 'discontinuity', in order to focus on whether a higher degree of social differentiation. In addition, gated communities are territories that differentiate from their surroundings especially on age criteria and socio-economic status. Siti and his team (2012) ${ }^{11)}$ compared sense of community between gated and non-gated community in Malaysia. They found that residents in non-gated residential areas have a stronger sense of community as compared to those in gated communities. These notions affirmed that physical elements of gated communities influences on social interaction of residents but depended on the context. According to those researches, studies of GHP's impact should be considered about both inside and outside social relationship, in order to realize the effects from GHP development in the district scale and community scale. The evaluation of social interaction between inside and outside GHP is significant for understanding impact of GHP. Thus, the social interaction assessment in this paper could not totally duplicate the western method, which concerned only inside GHP. It is necessary to apply some core value of social impact assessment because it involves with wider aspect of social relationship in district scale. The social impact assessment (SIA) embodies the evaluation of all impacts on humans and on all the ways in which people and communities interact with their socio-cultural, economic and biophysical surrounding (Vanclay, 2012) ${ }^{12}$. However, one of the core values of SIA is described as a way of conceptualizing social impacts in term of the quality of social relationship which is considered in people's way of life - that is, how they live, work, play and interact with one another on a day-to-day basis $^{11}$. In general social interaction literature, investigators have looked frequency of encounters between respondents and members of their social network, and counted the number of persons in the social network (Conner, et al, 1979) ${ }^{13}$. This means the measurement should cover not only inside their communities but also outside communities. Moreover, their findings are related with measurement of neighborhood interaction that is a part of sense of community evaluation. This conceptual idea about social interaction assessment is appropriate to apply for this study in BMR context. 
communities of study area. The questionnaires were distributed by face-to-face acquirement during March 12-14, 2013. As the formula, the sample size is 400 people when sampling error is 0.05 and population is 126,562 people in the case study area. However, the number of the responses of the questionnaires depended on private property permission and cooperation of residents in the five different types of community. It was difficult to gather all 400 questionnaires. For an instant, the questionnaires could not be distributed directly to respondents in GHP-D and GHP-T. GHP's juristic committee was as a presenter of us to spread the questionnaire sheets. In this situation, the number of respondents is limited. Finally, 363 questionnaires were collected in different types of community (as shown the number in Table-3). Therefore, the study results were displayed in percentage (\%) and with utilizing the mean of choice to create comparable outcome. The results came from questions that assessed sense of community for inside relationship (IR) and behavior of outside activities for outside relationship (OR). The answers were evaluated via statistic calculation and qualitative analysis.

Table 3 Questionnaire result (part 1-2)

\begin{tabular}{|c|c|c|c|c|c|}
\hline Types of community & FV & GHP-D & GHP-T & HP & $\mathrm{IH}$ \\
\hline Number of community & 8 & 15 & 7 & 2 & 1 \\
\hline Number of respondents & $\mathrm{N}=44$ & $\mathrm{~N}=56$ & $\mathrm{~N}=27$ & $\mathrm{~N}=183$ & $\mathrm{~N}=54$ \\
\hline $\begin{array}{l}\text { Age } \\
\text { (yrs) }\end{array}$ & \begin{tabular}{|l|} 
Mean: 48.71 \\
$\mathrm{~N}=41$ \\
(Std. 15.865) \\
\end{tabular} & \begin{tabular}{|l|} 
Mean: 40.25 \\
$\mathrm{~N}=55$ \\
(Std. 10.251) \\
\end{tabular} & \begin{tabular}{|l|} 
Mean: 35.45 \\
$\mathrm{~N}=22$ \\
(Std. 10.600) \\
\end{tabular} & \begin{tabular}{|l|} 
Mean: 38.88 \\
$\mathrm{~N}=181$ \\
(Std. 13.739) \\
\end{tabular} & \begin{tabular}{|l|} 
Mean: 35.31 \\
$\mathrm{~N}=48$ \\
$($ Std. 8.085$)$ \\
\end{tabular} \\
\hline $\begin{array}{l}\text { Family member } \\
\text { (persons) }\end{array}$ & \begin{tabular}{|l|} 
Mean: 4.35 \\
$\mathrm{~N}=37$ \\
(Std. 1.932) \\
\end{tabular} & \begin{tabular}{|l|} 
Mean: 3.72 \\
$\mathrm{~N}=43$ \\
(Std. 1.161) \\
\end{tabular} & \begin{tabular}{|l|} 
Mean: 4.11 \\
$\mathrm{~N}=19$ \\
(Std. 1.761) \\
\end{tabular} & \begin{tabular}{|l|} 
Mean: 3.93 \\
$\mathrm{~N}=167$ \\
(Std. 1.602$)$ \\
\end{tabular} & \begin{tabular}{|l|} 
Mean: 5.18 \\
$\mathrm{~N}=45$ \\
$($ Std. 2.579$)$ \\
\end{tabular} \\
\hline $\begin{array}{l}\text { Time to go to work } \\
\text { (mins) }\end{array}$ & \begin{tabular}{|l|} 
Mean: 31.82 \\
$\mathrm{~N}=11$ \\
(Std. 32.655) \\
\end{tabular} & \begin{tabular}{|l|} 
Mean: 39.34 \\
$\mathrm{N}=38$ \\
(Std. 22.636) \\
\end{tabular} & \begin{tabular}{|l|} 
Mean: 36.92 \\
$\mathrm{~N}=13$ \\
(Std. 18.989) \\
\end{tabular} & \begin{tabular}{|l|} 
Mean: 33.04 \\
$\mathrm{~N}=67$ \\
(Std. 23.061) \\
\end{tabular} & \begin{tabular}{|l|} 
Mean: 19.45 \\
$\mathrm{~N}=33$ \\
(Std. 17.813) \\
\end{tabular} \\
\hline $\begin{array}{l}\text { Period of dwelling } \\
\text { (yrs) }\end{array}$ & \begin{tabular}{|l|} 
Mean: 30.53 \\
$\mathrm{N}=36$ \\
(Std.19.921)
\end{tabular} & $\begin{array}{l}\text { Mean: 5.68 } \\
\mathrm{N}=53 \\
\text { (Std. } 9.131)\end{array}$ & \begin{tabular}{|l|} 
Mean: 10.00 \\
$\mathrm{~N}=21$ \\
(Std. 18.921)
\end{tabular} & \begin{tabular}{|l|} 
Mean: 9.14 \\
$\mathrm{~N}=169$ \\
(Std. 7.506$)$
\end{tabular} & \begin{tabular}{|l|} 
Mean: 19.00 \\
$\mathrm{~N}=46$ \\
(Std. 12.944)
\end{tabular} \\
\hline Occupation $(\%(\mathrm{~N}))$ & $\mathrm{N}=39$ & $\mathrm{~N}=54$ & $\mathrm{~N}=23$ & $\mathrm{~N}=179$ & $\mathrm{~N}=50$ \\
\hline Government officer & $20.5 \%(8)$ & $42.6 \%(23)$ & $30.4 \%(7)$ & $12.8 \%(23)$ & $40.0 \%(20)$ \\
\hline Company officer & $0.0 \%(0)$ & $13.0 \%(7)$ & $26.1 \%(6)$ & $16.8 \%(30)$ & $14.0 \%(7)$ \\
\hline Business owner & $2.6 \%(1)$ & $33.3 \%(18)$ & $21.7 \%(5)$ & $17.3 \%(31)$ & $6.0 \%(3)$ \\
\hline Shopkeeper & $46.2 \%(18)$ & $27.7 \%(13)$ & $13.0 \%(3)$ & $21.8 \%$ & $20.0 \%(10)$ \\
\hline Freelance & $2.6 \%(1)$ & $3.7 \%(2)$ & $8.7 \%(2)$ & $18.4 \%(33)$ & $4.0 \%(2)$ \\
\hline Other & $28.2 \%(11)$ & $3.7 \%(2)$ & $0.0 \%(0)$ & $12.8 \%(23)$ & $16.0 \%(8)$ \\
\hline Workplace $(\%(\mathrm{~N}))$ & $\mathrm{N}=38$ & $\mathrm{~N}=54$ & $\mathrm{~N}=23$ & $\mathrm{~N}=171$ & $\mathrm{~N}=50$ \\
\hline Bangkok city & $13.2 \%(5)$ & $40.7 \%(22)$ & $52.2 \%(12)$ & $22.2 \%(38)$ & $16.0 \%(8)$ \\
\hline Vicinity (Nonthaburi) & $23.7 \%(9)$ & $48.1 \%$ & $39.1 \%(9)$ & $26.9 \%(46)$ & $74.0 \%$ \\
\hline Work at Home & $52.6 \%$ & $7.4 \%(4)$ & $4.3 \%(1)$ & $39.2 \%(67)$ & $8.0 \%(4)$ \\
\hline Unemployed & $10.5 \%(4)$ & $3.7 \%(2)$ & $4.3 \%(1)$ & $11.7 \%(20)$ & $2.0 \%(1)$ \\
\hline Salary $(\%(\mathrm{~N}))$ & $\mathrm{N}=39$ & $\mathrm{~N}=54$ & $\mathrm{~N}=23$ & $\mathrm{~N}=176$ & $\mathrm{~N}=49$ \\
\hline Under 10,000 B. & $28.2 \%(11)$ & $3.7 \%(2)$ & $4.3 \%(1)$ & $13.6 \%(24)$ & $20.4 \%(10)$ \\
\hline $10,001-30,000 \mathrm{~B}$. & $43.6 \%$ & $24.1 \%(13)$ & $65.2 \%$ & $50.0 \%(88)$ & $55.1 \%(27)$ \\
\hline $30,001-50,000 \mathrm{~B}$. & $12.8 \%(5)$ & $24.1 \%(13)$ & $21.7 \%(5)$ & $19.9 \%(35)$ & $14.3 \%(7)$ \\
\hline $50,001-70,000 \mathrm{~B}$. & $7.7 \%(3)$ & $11.1 \%(6)$ & $8.7 \%(2)$ & $8.5 \%(15)$ & $6.1 \%(3)$ \\
\hline Over $70,000 \mathrm{~B}$ & $7.7 \%(3)$ & $37.0 \%(20)$ & $0.0 \%(0)$ & $8.0 \%(14)$ & $4.1 \%(2)$ \\
\hline $\begin{array}{l}\text { Reason to move in }(\%(\mathrm{~N})) \\
\text { (Multiple choices' question) }\end{array}$ & $\mathrm{N}=66$ & $\mathrm{~N}=119$ & $\mathrm{~N}=40$ & $\mathrm{~N}=261$ & $\mathrm{~N}=68$ \\
\hline Near workplace & $12.1 \%(8)$ & $17.6 \%(21) 9$ & $17.5 \%(7)$ & $23.4 \%(61)$ & $30.9 \%(21)$ \\
\hline Affordable price & $6.1 \%(4)$ & $18.5 \%(22) 9$ & $17.5 \%(7)$ & $14.9 \%(39)$ & $7.4 \%(5)$ \\
\hline Good design and material & $3.0 \%(2)$ & $7.6 \%(9)$ & $0.0 \%(0)$ & $2.3 \%(6)$ & $1.5 \%(1)$ \\
\hline Proper size & $9.1 \%(6)$ & $16.8 \%(20)$ & $22.5 \%(9)$ & $8.4 \%(22)$ & $7.4 \%(5)$ \\
\hline Creditable developer & $0.0 \%(0)$ & $5.0 \%(6)$ & $2.5 \%(1)$ & $1.1 \%(3)$ & $1.5 \%(1)$ \\
\hline Good environment inside & $3.0 \%(2)$ & $9.2 \%(11)$ & $5.0 \%(2)$ & $1.5 \%(4)$ & $2.9 \%(2)$ \\
\hline Good environment outside & $1.5 \%(1)$ & $8.4 \%(10)$ & $7.5 \%(3)$ & $5.7 \%(15)$ & $1.5 \%(1)$ \\
\hline Lively community & $12.1 \%(8)$ & $6.7 \%(8)$ & $10.0 \%(4)$ & $6.1 \%(16)$ & $11.8 \%(8)$ \\
\hline Near public facility & $10.6 \%(7)$ & $5.0 \%(6)$ & $12.5 \%(5)$ & $14.9 \%(39)$ & $4.4 \%(3)$ \\
\hline Birthplace & $21.2 \%(14)$ & $1.7 \%(2)$ & $0.0 \%(0)$ & $1.5 \%(4)$ & $19.1 \%(13)$ \\
\hline Former agriculturist here & $4.5 \%(3)$ & $0.8 \%$ & $0.0 \%(0)$ & $5.4 \%(14)$ & $5.9 \%(4)$ \\
\hline Family move in & $12.1 \%(8)$ & $0.0 \%(0)$ & $2.7 \%(1)$ & $6.5 \%(17)$ & $2.9 \%(2)$ \\
\hline Other & $4.5 \%(3)$ & $2.5 \%(3)$ & $2.5 \%(1)$ & $8.0 \%(21)$ & $2.9 \%(2)$ \\
\hline
\end{tabular}

5. Social Interaction Survey for inside and outside community

\subsection{Background of respondents}

To understand overall background of respondents in the case study area, the results were analyzed by descriptive statistic such as frequency, percentage, and means. We revealed different background of residents that could reflect social class of residents. The length of occupancy related with social relationship as mentioned in previous work (Siti et. al, 2012) ${ }^{11)}$. The longer period they lived, the stronger bond of community they had. The average period of dwelling of FV was extremely longer than others. One of main reasons was FV's birthplace, thus it could be assumed that FV is the real local people. The traffic congestion could be reflected via wasting much time to workplaces of GHP-D even their workplaces were in Nonthaburi province. The heterogeneity of residents in district could mirror through different income of respondents, which related with social relationship ${ }^{11)}$. The average income of respondents in FV, GHP-T, HP, and IH was low to middle class $(\sim 94,500 \mathrm{JPY}$ per month). On the other hand, GHP-D's income was over 70,000 THB $(220,500$ JPY ) as high-class society in the study

area. This situation of heterogeneity of economic possibly led to segregation of social relationship in district scale because wealthy people needed to protect themselves from local population ${ }^{7)}$. Moreover, this evidence is illustrated with physical element of FV and HP community from physical observation in chapter 3. FV and HP had no restricted accesses, and this supported business activities in those communities. The reason for choosing to live in each community also shows respondents' priority of consideration for living. HP and IH likely concerns about location of workplace (23.4\% and 30.9\%). GHP-D focuses on affordable housing price (18.5\%) and size of house (17.6\%). This outcome seems to display that non-local people prioritized the choosing community by economic aspect. It is not the environment that is highly concerned by GHP-D or GHP-T. These results from part 1 and 2 of questionnaires show the dissimilarity of characteristics of residents in different type of community that will be discussed with social relationship in chapter 7.

\subsection{Neighborhood relationship between inside and outside community (Fig.5-7)}

Question 1.1-1.3 reflected sense as part of group through inside community participation and perception, called membership factor. Main respondents had positive perception with neighbors as shown in (1). The preference of respondents on 'taking responsibility in public area' and 'being committee of community' (Fig.5-1.1(1)(2)) shows 「mindedness on community」. GHP-T lacked of mindedness on common area(2). FV had high mindedness because as many as $20 \%$ of respondents like to be committee of community(3). Participation of respondents in common activities might show the activity that can promote a chance of social 
interaction as mentioned in section 4.1. Community meeting is determined in housing regulation for GHP ${ }^{3)}$. Voluntary activity reflects sacrifice of respondents. The significant results were; (4)Traditional or religious activity was a common interesting activity; (5)GHP-D regarded legal activity and realized importance of

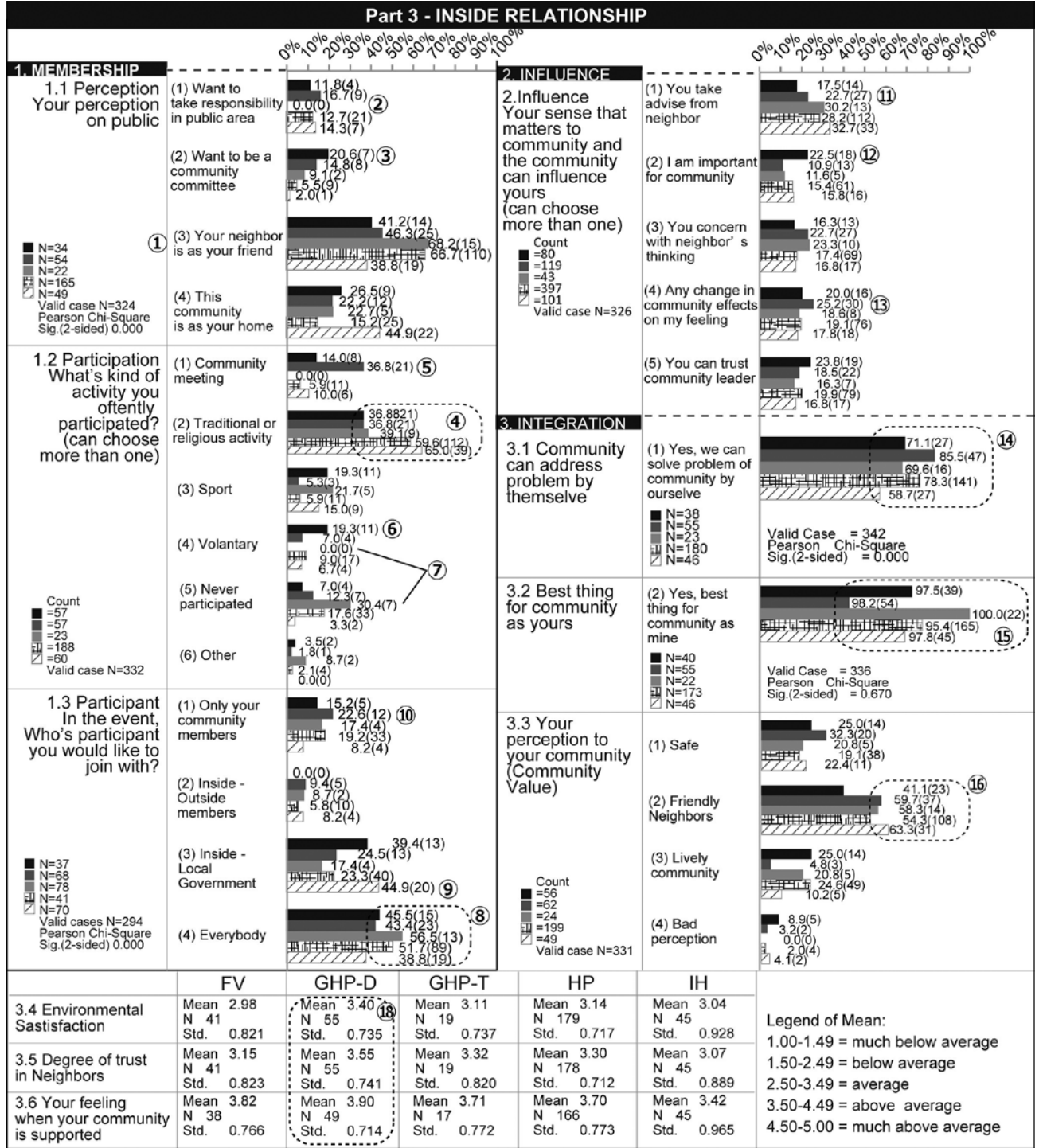

Fig.5 Results of questionnaire (Part3 - Relationship inside community) community committee; (6) FV were willing to scarify for others than another communities. At the same time, one third of respondents in GHP-T had no cooperation(7) and had no sacrifice for community (7). The prospected attendants in Fig.5-1.3 presented the closeness of community. Overall answers of question 1.3 show that almost a half of respondents in $\mathrm{FV}$, GHP-D, GHP-T, and HP is opened community (8). Whereas, IH prefers to attend with local government sector(9). GHP-D has as many as $22.6 \%$ of respondents (10) behaves like a closed community, thus it is found that nontraditional opinions about attending some inside activities (Fig.5-1.3). Question 2 illustrated factor of influence. Question 2(1), 2(3), and 2(5) reflected how 'neighbor' influenced to 'member'. Question 2(4) presented influence of community on respondents. Question 2(2) showed confidence of respondents to take action in community. As the results (Fig.5), overall respondents in GHP-T, $\mathrm{HP}$, and IH were affected by neighbors (11). This means 'neighbor' is an influencer of respondents. Meanwhile, FV is a confident person who can take responsibility in community (12). A

quarter respondent in GHP-D concern about 'changing community' (13). This can assume that GHP-D preferred to cooperate in activity for changing community. Question 3.1 -3.6 refers to the feeling or perception that needs are met through the cooperation behaviors of the community, called "integration" factor. Over a half of respondents agree that they rely on community's ability, especially GHP-D(14) and GHP-T(15). Question 3.3(2) reflects that most of respondents have positive thinking on neighbors(16). Moreover, the perception of safety(17) is obviously expressed in GHP-D (32.3\%) that shows good security system and its advantage. In Question 3.4-3.6, GHP-D reaches the highest score in satisfaction. This means the designed environment in GHP-D can fulfill needs and satisfaction of respondents (18). However, $85.5 \%$ of GHP-D still faces problems of living (19)such as illegal parking in common area and dirtiness in common area, according to face-to-face conversation. This might show problematic management system in GHP-D community.

In Fig. 6, Question 4.1.1-4.2.2 evaluates neighborhood interaction and community bond through frequency of interaction (Fig.6-4.1.1 - 4.1.5) and agreement (Fig.6-4.2.1-4.2.2). In FV, GHP-D, HP, and IH community have acquaintances over 15 people, which is contrast with GHP-T. GHP-T has only few acquaintances (Fig.6(1) and few friends in community (Fig.6(3)). Number of acquaintance and friend relate with frequency of talking to neighbor and make more chances of social interaction. Question 4(2) also investigates the way of respondents to meet, neighbors in nearby houses can facilitated the interaction (Fig.6(2)). These results can be supported by behavior of GHP for talking to neighbor in Question 4.1(5). Almost a half of GHP-T and GHP-D (Fig.6(5)) have never talked to neighbors, thus they are solitary. Around $30 \%$ of IH's respondents have never been visited by neighbors because of location of IH houses are not clear cluster (Fig.6(4)). That means neighbors of IH are hard to promote social interaction. 


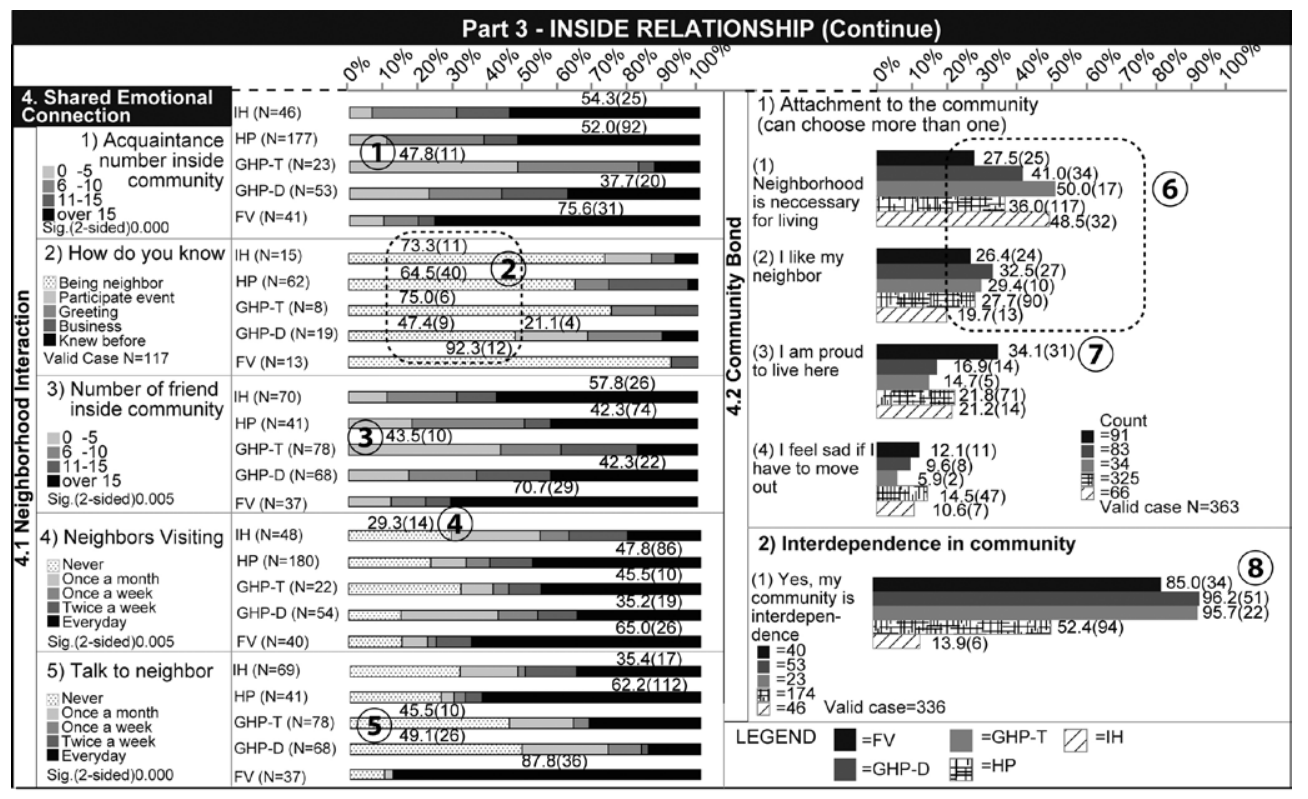

Fig.6 Results of questionnaire (Part3 - Relationship outside community (continue))

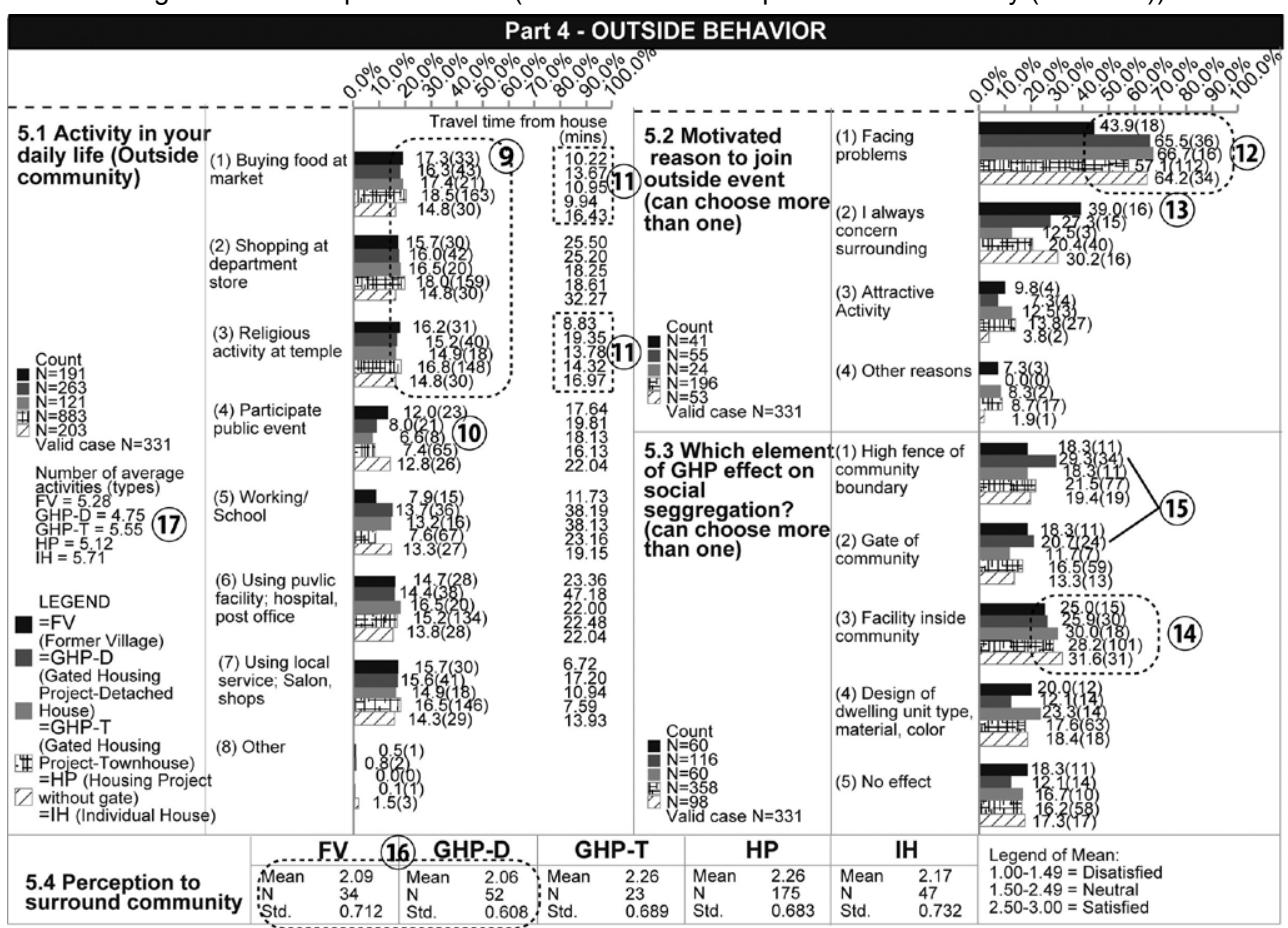

Fig.7 Results of questionnaire (Part4 - Relationship outside community)
Question 4.2(1)-4.2(2) presents bond between respondents and neighbors, while bond between respondents and community is showed in Question 4.2(3)-4.2(4). The study reveals GHP-D, GHP-T, HP, and IH attach with their neighbors, whereas FV attaches with community. Over $50 \%$ of respondents in FV, GHP-D, GHP-T, and HP believe neighbors can help them, except IH's respondents (Fig.68). This might reflect that unclear location of neighbors might impact on belief of community's ability. Fig.7 displays results of neighborhood relationship to outside community of respondents' opinion in study area that is evaluated by Question 5.1-5.4. This section might promote the way to make unification between five types of community in district scale. Question 5.1 tried to mirror 'common outside activities' and 'public place' to create opportunity of social interaction and node of district. 'Buying food at market', 'religious events at temple', and 'shopping at department store' seem to be common outside activities (Fig.79)). Moreover, column of travel time from home to do those activities reflects convenience of respondents' houses and potential of housing location. According to results, 'market' and 'temple' seem to be the most convenient place as nodes in the case study area because residents take only $9-15$ minutes to reach there (Fig.7 (11)). Additionally, 'public event' that is held at local

governmental office becomes a non-interesting activities for GHP-D, GHP-T, and HP (Fig.71(10). This opinion might be referred to difficulty for local government to make public hearing by residents' cooperation. The most motivate reason to lead respondents go outside community was 'facing problem' (Fig.7(12). Therefore, the public space for response their problems might be needed at the node of the case study area. Meanwhile FV's residents are people who have more public mind than others, they are willing to attend an outside activity without any condition (Fig.7(13)). Question 5.3 tries to analyze which physical elements of GHP impact on social segregation in which type of community. High fence, gate, and inside facilities are typical elements for GHP development. The study found that almost every type of community concerned about 'inside facilities' (Fig.7 (14)), but GHP-D focused on high fence of community (Fig.7(15)). This evidence supported that GHP-D needed more segregation from surrounding community by the fence. Question 5.4 presented perception of respondents on surrounding community. We found FV and GHP-D have lower scale of perception to surrounding (Fig.7(16) than others. The result was expected that FV be supposed to have not good perception on outside community because we found many principle problems via physical observation in chapter 3 such as threat on farmland and obstructed accessibility. However, the unexpected result was revealed that GHP-T had better perception on surrounding community. This point will be discussed in conclusion part. 


\section{Attitude of external stakeholder (developers and local government officers)}

Beside the opinion of residents in study area, external stakeholders such as developers and local government officers were asked for their attitude and current situation of GHP development in the case study area. We interviewed a representative of private developer ${ }^{* 3)}$ who is a local housing company in this area. The higher land cost (up to 80,000 JPY/sq.m.) led to increase trading of agricultural lands to new housing projects. In his opinion, FV could adjust their life styles to survive in this urbanized situation in this area. Moreover, size of GHP should be limited because it is difficult to set juristic committee for self-maintenance after full occupancy. He mentioned additionally that the environmental impact of GHP could be reduced with collaboration between private and public sector. This conversation could reflect developers had no idea about social impact but they realized the importance of GHP improvement. Nevertheless, mayor of Bangmuang district*4), who was born in this area, shared different attitude. He confirmed the impact of GHP on FV in existing situation such as environmental problem and participation problems. The FV is located on intersection of three main canals where there was the way of water drainage from every community. Although wastewater treatment of GHP was strictly controlled, there were illegal wastewater releasing in rainy season and some under standard treatment. Consequently, FV could not consume natural water in the canals and could not produce agricultural products, which led to change of their life styles to commercial activity and cultural tourism. Therefore, the issue of wastewater release was one of causes that affected on perception of FV on surrounding community. Moreover, mayor described about the difficulty of making development plan in this area because it lacked of cooperation from GHP communities. From the interview, we revealed that both stakeholders know the impact of GHP on FV's life style but it lacks of collaboration all relevant stakeholder and community in order to reduce the effects and figure out the compromising solution. The evidences from interview can be supportive results to discuss the cause of social impact of residents in the case study area.

\section{Conclusion}

The objective of this paper is to assess the social interaction between inside and outside GHP community. The prospected outcome is an answer to the question; how to enhance interaction and create integration in the case study area. We found the behaviors of the different community types that related with social relationship (Table 4), namely, FV is local community which only active among its members(1). Thus, its inside relationship is better than other communities. This findings support Siti, et al. (2012) ${ }^{11)}$, which also found non-gated community had higher sense of community than gated community. Another previous studies supported that environment within gated community could motivate social interaction among residents through common recreation and clear boundaries ${ }^{73)}$. The findings of this study argued that GHP community lacked of social interaction, even it provided well environmental design. The evidences showed that GHP-T and GHP-D have solitary characters and lack of participation with neighbors(2). The expected finding is an increase of community isolation by GHP development because its location blocks accessibility to FV (as shown in physical observation) from the road network. Moreover, the extraordinary income in GHP-D(3) also leads to heterogeneity of residents' profile and separation from local community. This evidence supports why GHP-D regards high-fence(4) and restrict security. This consequence was also found by Low (2003) and

Table 4 Characteristics of five types of community

\begin{tabular}{|c|c|c|c|c|c|}
\hline Attribute of respondents & FV & GHP-D & GHP-T & $\mathrm{HP}$ & $\mathrm{IH}$ \\
\hline Average Period of living (yrs) & 30.53(1). & 5.68 & 10.00 & 9.14 & 19.00 \\
\hline Occupation & Shopkeeper & Mixed & Mixed & Mixed & Government officers \\
\hline Average Income (THB) & $10,001-30,000$ & Over 70,000(3) & $10,001-30,000$ & $10,001-30,000$ & $10,001-30,000$ \\
\hline Inside social relationship & FV & GHP-D & GHP-T & $\mathrm{HP}$ & $\mathrm{IH}$ \\
\hline Common interest activities (6) & $\begin{array}{l}\text { Traditional } \\
\text { Voluntary }\end{array}$ & $\begin{array}{c}\text { Traditional } \\
\text { Community meeting }\end{array}$ & $\begin{array}{l}\text { Traditional } \\
\text { Sport }\end{array}$ & Traditional & Traditional \\
\hline Low interest activities & ( & Sport & $\begin{array}{c}\text { Community meeting } \\
\text { Voluntary } \\
\text { Never participated } 8\end{array}$ & $\begin{array}{c}\text { Community } \\
\text { meeting } \\
\text { Sport } \\
\end{array}$ & Voluntary \\
\hline Perception inside community & \multicolumn{5}{|c|}{ Friendly neighbors (7) } \\
\hline Friends (persons) & Over 15(1). & Over 15 & $0-5$ & Over 15 & Over 15 \\
\hline The way to interact & \multicolumn{5}{|c|}{ Being neighbors who live nearby(7) } \\
\hline Frequency of social interaction & $\begin{array}{c}\text { Almost } \\
\text { everyday(1). }\end{array}$ & $\begin{array}{l}\text { Never talk to } \\
\text { neighbor(2) }\end{array}$ & $\begin{array}{l}\text { Never talk to neighbor } \\
\text { (2) }\end{array}$ & $\begin{array}{c}\text { Almost } \\
\text { everyday }\end{array}$ & Almost everyday \\
\hline Community bond & $\begin{array}{c}\begin{array}{c}\text { Proud to live } \\
\text { here }\end{array} \\
\end{array}$ & \multicolumn{4}{|c|}{ Neighborhood is important $(7)$} \\
\hline Outside social relationship & FV & GHP-D & GHP-T & HP & $\mathrm{IH}$ \\
\hline Frequent activities and place & \multicolumn{5}{|c|}{ Buying food (market) (9) } \\
\hline $\begin{array}{l}\text { Number of outside activities } \\
\text { (activities) }\end{array}$ & 4.63 & 4.75 & $5.26(5)$ & 4.87 & 3.92 \\
\hline Motivate reasons & \multicolumn{5}{|c|}{ Facing problems (10) } \\
\hline $\begin{array}{l}\text { Segregation from GHP } \\
\text { elements }\end{array}$ & $\begin{array}{c}\text { Common } \\
\text { facility }\end{array}$ & High fences (4) & \multicolumn{3}{|c|}{ Common facility } \\
\hline Perception on surrounding & 2.09 & 2.06 & $2.26(5)$ & 2.26 & 2.17 \\
\hline
\end{tabular}

Siti (2012) that difference of economic brought about demand of protection as wealthy people. In Nonthaburi context, we likewise revealed outside relationship of $\mathrm{FV}$ is weaker than expectation because it is affected from GHP development. This was caused by wastewater release, and encroachment on FV's agricultural lands and accessibility, according to local government interview result. Another unexpected finding is that GHP-T has the strongest outside relationship as the result showed the highest number of participation in many outside activities(5) and positive perception on surrounding communities(5). According to whole results above, we can assume that current environmental design and community management of GHP should be reconsidered because it cannot enhance inside social interaction and improve outside relationship of other communities. They may lead to difficulty of making unification for local government when they need to enhance social interaction of residents. Therefore, the study suggests that GHP community should be improved inside social relationship through enhancing opportunity of interaction such as traditional activities (common interesting activity) 6). The 
initiator of activity should be from neighbors because they are important influencers of GHP(7). The current system of community management is not practicable for arranging a meeting because it still leads to problems on common area and less participation (8) in the meeting. Hence the scale of meeting should be in neighborhood scale not in community scale. Providing areas in markets and temples(9) for multiple-purposes should enhance to create social integration in district. For example, a mutual-aid center for unpredictable crisis experience(10) to lead member sharing more community value should hold at the market or temple, including areas for public event from local government. Finally, the upcoming-gated housing projects should pay more attention on former communities with redesigning the gates and fences, and choosing location, in order to reduce impacts in the future.

\section{Notes}

*1) Bangkok Metropolitan Region (BMR), as the national plan, includes 6 administrative provinces are; 1) Bangkok city: 1,568.737 km², 5,702,595 people, 2) Nakhonpathom: 2,168.327 km², 851,426 people, 3) Nonthaburi: $622.303 \mathrm{~km}^{2}, 1,078,071$ people, 4) Pathumthani: 1,525.856 km², 956,376 people, 5) Samutprakan: 1,004.092 km², $1,164,105$ people, and 6) Samutsakhon: $872.347 \mathrm{~km}^{2}, 484,606$ people. Total BMR area is 7,761.662 $\mathrm{km}^{2}$ and number of residents is $10,237,179$ people. It consists of 69

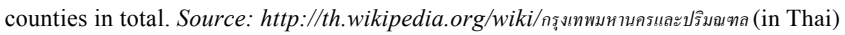

*2) Average crimes (2003-2012) ${ }^{15}$ compares with number of residential unit in GHP $(2013)^{16}$ in vicinity area; 1) Nonthaburi: 1,666 cases, 31,587 units, 2) Pathumthani: 1,970 cases, 28,288 units, 3) Samutsakhon: 1,003 cases, 11,934 units, 4) Samutprakan: 1,825 cases, 25,818 units, 5) Nakhonpathom: 1,308 cases, 4,335 units.

*3) Interviewee: Dr.Pairoj Sukjan, President of Buathong Property Company Limited, 2013.03.13

*4) Interviewee: Mr.Pornthep Pradubploy, Mayor of municipality of Bangmuang subdistrict, 2013.03.11

\section{References}

1) Kinmalai, Siwaporn, and Kanki, Kiyoko : Urban Sprawl Classification and Composition Analysis of Land use including Gated Housing Development in Bangkok Metropolitan Region, Thailand, Journal of Architecture and Planning (Transaction of AIJ) Vol. 78 No. 694, p. 2537-2546, 2013.12

2) National economic and Social Development Board office of the Prime Minister Bangkok : Key issues of the main programs, the sixth National Economic and Social Development (1987-1991), p. 17, 1987

3) Blakely, J., Edward, and Snyder, G., Mary : Forstress America: gated communities in the United States, D.C., Brookings Institution Press, Washington, 1997

4) Klinmalai, S. and Kanki, K. : Impact of residential landform and land use transformation in greater area of Bangkok, Thailand: $11^{\text {th }}$ International Congress Asian Planning School Association Conference proceeding p. 46, The university of Tokyo, 2011

5) Kinmalai, Siwaporn, and Kanki, Kiyoko : Neighborhood assessment between inside and outside gated housing projects in sprawl area of Bangkok Metropolitan Region - The Case of Pathumthani Province where the different Gated Housing Projects and Farmer villages are located adjacently, Journal of the City Planning Institute of Japan Vol. 48, p. 279-284, 2013

6) Bartle, Phil : What is Community? A Sociological Perspective, World Wide Web page < http://cec.vcn.bc.ca/cmp/whatcom.htm>, 2013.10.30

7) Low, Setha : Behind the gates: Life, security, and the pursuit of happiness in fortress America, Routledge, New York, 2003

8) Department of Lands : Regulation of land allocation for residence and commerce in Bangkok, Government Gazette Vol. 124, p. 47-63, 2007.02 (in Thai)

9) Buckner, C., John : The development of an instrument to measure neighborhood cohesion, American Journal of Community Psychology Vol. 16 No.6, p. 771-791, 1988

10) Le, Goix, Renaud : Gated communities: Sprawl and social segregation in southern California, The International Conference on gated communities, Glasgow, September 18-19, 2003

11) Siti Rasidah Md Sakip, Naraini Johari, and Mohd Najib Mohd Salleh : Sense of Community in Gated and Non-Gated Residential Neighborhoods, Procedia - Social and Behavioral Sciences, Vol. 50, p. 818-826, 2012

12) Vanclay, Frank : International Principles For Social Impact Assessment, Impact Assessment and Project Appraisal Vol. 5 No.1, p. 5-12, 2012

13) Conner, A., Karen, Powers, A., Edward, and Bultena, L., Gordon : Social Interaction and Life Satisfaction: An Empirical Assessment of Late-Life Patterns, Journal of Gerontology, Vol. 34, No. 1, p. 116-121, 1979

14) Sawicki, S., David and Flynn, Patrice : Neighborhood Indicators: A review of the literature and an assessment of conceptual and methodological issue, Journal of the American Planning Association Vol. 62:2, p. 165-183, 1996

15) Statistical Forecasting Bureau : Statistics of reported and arrested for the group of crimes against property by type of reported cases, World Wide Web page $<$ http://service.nso.go.th/nso/web/statseries/statseries13.html>, 2014.08 .12 (in Thai)

16) Government Housing Bank : Housing Market in 2013, p. 36-41, 2013 (in Thai)

\section{和文要約}

本研究は、バンコク大都市圈内の周辺県のひとつノンタブリ県を対

象として、急速にスプロール化が進む中でとりわけゲーテッド・コミ ユニティ(本論文では住民のもつ人間関係としてのコミュニティと表 現が重複しないように、ゲーテッド・住宅開発と表現する）と既存の 集落・住宅地が混在するエリアを対象とし、塀等で封鎖し既存の周辺 住宅地等との関係性の形成に無配慮とみられるゲーテッド・コミュニ ティの内外にわたって、混在する各コミュニティの居住者による近隣 関係性の評価を行ったものである。ノンタブリ県は、バンコクの都市 化前の農村エリアによくみられるように、複雑な形態の水路網が拡が りその水路沿いに小規模な旧集落が立地していたところに、不規則な かたちの土地形状の上に新たな住宅開発が集積しつつある対象地で
ある。まず、現地調査により、ゲーテッド・コミュニティの集積が既 存の集落の孤立化や通行の支障が生じる対象エリアの状況を確認し た上で、訪問アンケート、インタビューを行った。その結果、タウン 八ウスのゲーテッド・コミュニティは戸建て住宅のゲーテッド・八ウ ジングよりも内外ともにコミュニティ意識が弱く、ゲート・塀のない 住宅開発地や個々に住宅が増えた地区は互いの交流は少ないものの 内部のコミュニティには信頼感をもっており、旧集落がもっとも内部 コミュニティや周辺地区との関係性の形成への意識をもっていた。し かし旧集落は周辺の開発進行に伴い転出がみられる。これらの結果か ら、現在の各地区の内外にわたる関係性の拡大の可能性と課題を考察 した。

（2014年 1 月10日原稿受理，2014年 9 月19日採用決定） 